\title{
Portrayal of Mughal Tents as a Provisional Capital
}

\author{
Naseer Ahmad Mir \\ Research Scholar, Centre of Advanced Study Department of History, AMU, Aligarh. \\ naseerhis.amu@gmail.com
}

\begin{abstract}
The great Mughals known for their grandeur was expressed and observed both by Asians as well as by the European travellers. Besides, these sources provide us information on various fields of Mughal history, here I have focused on their day to day travel and tent settlement. An endeavour has been made to look how these tents acted as weather shields and transitory capitals moreover ensured their pomp and highness.
\end{abstract}

The Mughals magnificence has been positively acknowledged by a number of people including contemporaries. Thesplendour of Mughals was communicated both in private as well as in their public life. So as to run the administrationefficiently it was important to keep a vigil peering toward on the general population undertakings, for this the Mughal sovereigns used to movement long distances. The evaluated travel they went with their extensive camps was around $16 \mathrm{~km}$ for each day. What's more, toward the finish of day they rested in the place like tents, however transitory. Mughal rulers spent about $40 \%$ of their time in the camps while on visits and the span of such tours frequently enduring a year or more. On one occasion Emperor Jahangir was away from his capital Agra for five years and seven months. ${ }^{1}$ The political importance of Mughal imperial cities kept on being exceptionally constrained; it was physical portability which stayed at the focal point of Mughal magnificent court life and, for a significant part of the Mughal period, the royal court was typified in the physical nearness of the lord. Mughals presented the few aspects of Central Asian culture to India. Monika Gronke, contended that the mobility of Timur's court, and that of his prompt successors, can be ascribed to their parentage and even be viewed as a 'transitional stage' between obvious nomadism and the stationary life. ${ }^{2}$ Fray Sabastian Manrique opined that after reaching Lahore, more than a half league of the adjoining country was covered by a handsome well laid-out, moving town, composed of variety of tents and pavilions of many colours, affording to the eye a pleasant landscape. ${ }^{3}$

The journey was travelled in interims. Mughals adopted various traditions of Persia. Among these we can see their following in gardens, large and lovely tents too. The Persian works, for example, Epic of Gilgamesh, the EnumaElish, the Code of Hammurabi, Zoroastrian writings (e.g. Vendidad and Yasna), and the Book of Genesis don't straightforwardly talk about the structure in gardensbut, they obviously mirror the improvement of the predominant cultural view on gardens in the region. The English word pavilion is used here as a cover term for an assortment of terms used as a part of Persian writing and recorded archives. For instance, in Persian the following terms have been used to depict a pavilion in a characteristic setting: kushk, emarat, khaneh, qasr, talar, kakh, Khaimeh, sardaq, andkhargah. Contingent upon the specific circumstance, these words allude to the utilization of the pavilion as kiosks, royal residences, houses, or just as spots for unwinding. While some of these terms (emarat, khaneh, qasr, moshkuy, sarai, shabistan, tagh, iwan, and kakh) allude to the pavilion as a changeless structure, alternate terms (kushk, khaimeh, sardaq, andkhargah) allude to transitory structures in gardens. ${ }^{4}$ In contrast to the discussed terms for pavilions, all of which allude to permanent structures, khaimeh, khargah, and sardagh, allude to tents with various sizes. As opposed to khaimeh, which is very basic and simple to erect, khargah and sardagh allude to tremendous and complex tents which may even contain littler tents inside them. ${ }^{5}$ The mobile nature of pavilion has been dominant to the point that its equivalent term in Persian, paloon, signifies 'packsaddle' ${ }^{6} \mathrm{An}$ impeccable pavilion ought to be enormous in stature.

www.arjonline.org

Page 1 
We can envision the trouble of carrying all these tents and the court's furniture between gardens. This marvel wasobserved by Anthony Jenkinson (1529-1610/1611 AD), the British explorer who records his perceptions of a mobileordu (a camp) in Central Asia in the sixteenth century: "by estimation around a thousand camels drawing of carts with houses upon them like tents, of an odd form, appearing to be far away a town. ${ }^{7}$ Clavijo, whose notes clear up the social life in tents, tent structure and ornamentation, and even their arrangement in gardens, records his perceptions of the Timurid settlements outside the city of Nishapur. ${ }^{8}$

The Mughals were exceedingly inclined toward camp life and in this manner a decent arrangement of time was spent in movement. The Mughal camp resembled a moving city. ${ }^{9}$ When the King goes in the military grandeur he was having constantly two private camps; one of these grounds being a day progress of the other, the ruler was certain to discover toward the finish of voyage, a camp completely arranged for his reception. It was therefore for that reason, the different collections of tents were called piche-kanes or houses which continue. Amid the walk a camel with white materials went before the ruler, in order to cover over any dead creature or person found out on the road ${ }^{10}$ and the water transporters kept running in front sprinkling the roads to keep the dust from rising. ${ }^{11}$ The vehicle required for one camp to move was in excess of sixty elephants, two hundred camels, one hundred donkeys and one hundred men porters. The weighty tents with their heavy poles were conveyed by elephants. The bigger tents were made of timber and in actuality were compact portable structures. The littler tents are borne by camels and the baggage and kitchen utensils by the donkeys. Porters were in charge of safe carriage of significant articles like porcelain, the painted,gild beds and karguais (folding tents, some with one, others with two entryways were made in different ways. ${ }^{12}$

When the peiche - kanes achieve the new place for encampment, the Grand Quarter Master with different designers chooses the fitting site where the royal tents were to be emptied.The camp is separated in such a way that on entry of the armed force there might be no disarray. ${ }^{13} \mathrm{He}$ at that point denoted a square on which tent was to be pitched. The entire square is then occupied with kanates or screens, seven or eight feet in height, secured by lines appended to pegs and by poles settled two by two in the ground. These kanates were made of solid fabric with printed Indian calico speaking to extensive vases of blossoms. The roomy royal passage in one of the sides of square is of considerably better texture\&wealthier than rest. ${ }^{14}$

The first and biggest tent raised in the camp is named as Am-kas for ruler and the nobles, where they collect for consultation on state issues and for administering justice, yet the tents of Rajahs and nobles must not be as high as that of King; otherwise their tents would be thumped down. ${ }^{15}$ The second tent, minimal mediocre in estimate is called Gosle-kane or the place for showering. It wasthere that the nobles met the King at night. Still further in the square is the third tent called Kaluet - kane (place of Privy Council) littler than the above mentioned two tents. To this tent none,but the essential ministers of state could approach. ${ }^{16}$

Beyond the kaluet-kane there were Kings private tents encompassed by little kanates of the tallness of man, painted over with blossoms of hundred various types. Bordering the imperial tents are those of the princesses and chief female orderlies of seraglio. Amidst them are the tents of second rate female domestics, by and large put in request as per their occupation. ${ }^{17}$ On the highest point of high pole was alighted a lamp, which served in as a manual for the individuals who arrived late during the night. ${ }^{18}$

The important tents including Am-kas were lifted over the rest with the goal that they might be recognized at a separation. The outer side was secured with solid coarse red fabric and variegated stripes; but the inside was ornamented with brocade, velvet and fixed with wonderful hand painted chintz. Thick Cotton mats were spread over the entire of floor and these again werecovered with impressive rugs, on which are set expansive square brocade pads to lean upon. ${ }^{19}$

Two tents were most pompously decorated where stages were built, utilized by the King and the nobles for pondering and the ruler gives gathering of people under an open shelter of velvet. Alternate tents additionally contain karguais or cabinets, the little entryway of which was secured with silver padlocks. ${ }^{20}$ 
On either side of the regal entryway for the most part on the eastern end, there were two good looking tents, each holding nine choicest steeds, saddled for various purposes. Besides, the stirrup ordnance was made which fire a salute when the ruler goes into the camp. ${ }^{21}$ On the front door, on its limit was a tent called Nagar-kane ( Nakarah a drum and khanah a room, it was a beast kettledrum four feet high laying on the ground and played upon by one man with a couple of sticks). ${ }^{22}$ Near this tent was another vast size, called chauki-khanah, where the nobles in turn mount monitors for twenty - four hours, once every week. Most of them, pitch their tents in its environ to get more comfort and protection. ${ }^{23}$

The other three sides of huge square of the camp were covered by tents utilized for arms of the ruler, rich outfits, and vest of brocades, fruits, sweetmeats and Ganges water. There were fifteen or sixteen different tents which serve for kitchens and amidst all these are the tents of extraordinary number of officers and eunuchs. Six different tents of large size were for steeds, elephants,animals for chasing,for the birds of prey that go with the court, for the mutts; the panthers for catching gazelles. ${ }^{24}$

It was the obligation of Quarter Master to mark out the regal bazars, from which every one of the troops were provided the necessities. The primary bazaar was laid out as Wide Street with the tents having a place with the adherents of the armed force who offer their subsistence, going through the entire degree of the armed force. A pole is planted at the two closures of bazaars and recognized by a specific standard. It was a matter of privilege that the red shading was solely for royal tents and as a sign of regard every one of the tents needed to front the Am-kas. ${ }^{25}$ The nobles provided watchmen to prevent robberies who kept shouting out khaber-dar or have a care all the night. ${ }^{26}$

Amid the march the King was attended by eight donkeys conveying little tents for ruler's wish to rest or to eat a bit of something. ${ }^{27}$ Each trooper appears to have had the sanctuary of a tent, regardless of whether it comprised just of a cotton material raised on two sticks. There were numerous kinds of tents, from the little an insignificant low overhang, up to the enormous magnificent tents. The Ain-i-Akbari, I, 54, names twelve various types of tents. I have recently talked about one of these, the Uautl, and of another, the Gulallbar, not a tent but rather a fenced in area. The sarapardah was additionally a screen and not a tent. The Shamiyanah is yet known and commonly used in India; the name might be from sham, evening, that is a canopy for use at night, or from shamah (Steingass, 725), a shroud. The khargah, are discussed by Bernier, where he says they were folding tents with one or a couple of entryways, and made in different ways; he called them "cabinets", and leads us to surmise that they were set up inside the extensive tents. The emperor and the great nobles were furnished with tents in copy, one set being sent on to the following camping ground while the other set was being used. ${ }^{28}$ The tents in this manner sent on were known as the peshkhanah (literally "propel house"). ${ }^{29}$

Few tents were of a tremendous size. There was one made by the order of Shah Jahan which bore the name of Dil'badil (Generous Heart). ${ }^{30}$ Comparable sort of tent was ordered by Bahadur Shah to be raised at Lahore in the year 1711, five hundred tent-pitchers and carpenters were utilized for one month in putting it up, and in this manner a few people got killed. The aggregate use spent on it was around 50,000 rupees. A later author Seir, says the sovereign's camp was one and a quarter miles in circuit, it contained one hundred and twenty tents, some of them sufficiently huge for a few several men, and the biggest may concede two to three thousand. ${ }^{31}$ The tents of the ruler, his children, and grandsons were of a red fabric, called kharwah, a strong canvas-like cotton material, dyed red with the roots of the al plant. Round the ruler's tents was the nook called the gulalbar (The name of screen which Bernier discussed as being set up round the sovereign's tent.Gulal in Hindi signifies "red" and bar, "anything in the idea of a divider which counteracts passageway or entry through it" Before Akbar's time the tents of the Gurgani rulers were circumscribed by a rope called the tanab-i-quruq (the rope of hindrance). A portion of the colossal nobles, for example, the vice gerent (loahl-i-mutlaq) or the, chief minister Uamdatulmulk) were permitted patapati or striped tents, one red stripe and one white stripe then again. Outside the majestic tent, a ditch was dug out, and red flags, attributeof power, were shown on poles. 
Akbar demanded a Hindu Prince to destroy his tents, which were of red shading. He forced on the prince in command that he ought to never again utilize red tents and made it law that the Mughal Kings and the princes ofroyal blood should just be permitted to utilize tents of red shading. ${ }^{32}$ In 1607 Prince Khurram was conceded the utilization of parasol (aftabgir) and red tent which was the extraordinary right of eminence. ${ }^{33}$

All the great men attended him afoot; but when they went out of the town and the journey was long, he used to command them to mount a horseback.

At the point when Aurangzeb who kept dependably in the field, was to evacuate from place, where he lay with his armed force, a tent was conveyed before by a hundred and twenty elephants, 1400 camels and 400 little carts, to be set up where he was to encamp and a few a large number of steeds and foot, went along with 70 elephants to secure the ground for encampment. Eight different elephants conveyed eight chairs, more like coffins, fashioned with gold and silver, or gilt wood and shut with Cristal. There were three others conveyed by 8 men each, in one of which the King went, when he didn't mount the elephant, particularly on the off chance that it drizzled or the way was dusty. All the great men attended him afoot; however when they left the town and the voyage was long, he used to order them to mount a horseback. ${ }^{34}$

Aurangzeb moved his whole magnificent court to south, about emptied Delhi and sentenced the huge regal family to an extensive outcast from the (then) imperial Capital. ${ }^{35}$ Aurangzeb and his royal court moved into a makeshift camp, complete with bazaars, cantonments, authoritative officers and majestic quarters, from which the empire was ruled for 26 years. It thus gives the idea that the Mughals were tremendously concerned about their extravagance and power to rule with all offices, in wherever of their realm.

\section{REFERENCES}

1. Lisa Balabanlilar, The Emperor Jahangir and the Pursuit of Pleasure, Journal of the Royal Asiatic Society, Third Series, Vol. 19, No. 2, April 2009, p. 178.

2. Monika Gronke, The Persian Court Between Palace and Tent: From Timur to 'Abbas I, Timurid Art and Culture, ed. by Lisa Golombek and Maria Subtelney, Leiden, 1992 pp. 18-22.

3. Travels of Fray SabastianManrique 1629-1643, tr. C. Eckford Luard, Oxford, 1927, Vol. II, p.185.

4. Mohammad Gharipour, pavilion Structure in Persian-ate Gardens, Reflections in The Textual and Visual Media, May 2009, Thesis from Georgia Institute of Technology, p.51.

5. Ibid, p.53.

6. DehkhodaEncyclopedia of Persian Language (electronic version)

7. Anthony Jenkinson, Early Voyages and Travels to Russia and Persia, edited by Edward Delmar Morgan and Charles Henry Coote, The Hakluyt Society, 1886, p.55.

8. Clavijo, Ruy González de. Narrative of the Embassy of Ruy Gonzalez de Clavijo to the Court of Timour, translated by Clements Robert Markham, London: Hakluyt Society, 1859, p.107.

9. H.K.Naqvi, History of Mughal Government and Administration, Delhi, 1990, p.5.

10. NiccolaoManucci, Storia Do Mogor, tr. William Irvine, Calcutta, 1965, Vol. 1, p. 65.

11. H.K.Naqvi, History of Mughal Government and Administration, Delhi, 1990, p.58.

12. Francious Bernier Travels in the Mughal Empire 1656-58 Westminster London, 1891, p.359.

13. NiccolaoManucci, Storia Do Mogor, tr. William Irvine, Calcutta, 1965, Vol. 1, p. 67.

14. Francious Bernier Travels in the Mughal Empire 1656-58 Westminster London, 1891, p.360. 
Portrayal of Mughal Tents as a Provisional Capital

15. NiccolaoManucci, Storia Do Mogor, tr. William Irvine, Calcutta, 1965, Vol. 1, p. 68.

16. Francious Bernier Travels in the Mughal Empire 1656-58 Westminster London, 1891, p.361.

17. Ibid.

18. NiccolaoManucci, Storia Do Mogor, tr. William Irvine, Calcutta, 1965, Vol. 1, p. 68.

19. Francious Bernier Travels in the Mughal Empire 1656-58 Westminster London, 1891, p.362.

20. Ibid.

21. Ibid.

22. Ibid, p. 363.

23. Ibid, p. 362.

24. Ibid, p. 364.

25. Ibid, p.366.

26. Ibid, p.369.

27. NiccolaoManucci, Storia Do Mogor, tr. William Irvine, Calcutta, 1965, Vol. 1, p. 62.

28. Francious Bernier Travels in the Mughal Empire 1656-58 Westminster London, 1891, p.359.

29. WIlliam Irvine, The Army of the Indian Mughals: Its Organization and Administration, London, 1903, p.195.

30. Ibid, p.198.

31. Ibid, p.198.

32. NiccolaoManucci, Storia Do Mogor, tr. William Irvine, Calcutta, 1965, Vol. 1, p. 134

33. Inayat Khan, Shah Jahan Nama, tr. A.R. Fuller, ed. And completed W.E. Begley and Z.A. Desai, Delhi, 1990, p.5.

34. J. Ovington, India In the Seventeenth Century, ed. J.P. Guha, New Delhi, rpt, 1984, Vol. II, p.287.

35. Hamid-ud-Din Bahadur, Ahkam-iAlamgir, tr. byJadunath Sarkar as Anecdotes of Aurangzeb, (London, 1988) (1st and 2nd ed. 1925; 3rd 1949), p. 74.

Citation: Naseer Ahmad Mir. "Portrayal of Mughal Tents as a Provisional Capital". American Research Journal of Humanities and Social Sciences, vol 4, no. 1, 2018, pp. 1-5.

Copyright (C) 2018 Naseer Ahmad Mir. This is an open access article distributed under the Creative Commons Attribution License, which permits unrestricted use, distribution, and reproduction in any medium, provided the original work is properly cited. 